\title{
Standardization and Toxicological Studies of The Leaf of Senna Siamea Irwin and Barneby (Fabaceae) Collected From Agulu In Awka South of Anambra State
}

\author{
N.J. Alieze ${ }^{1}$, F.A. Onyegbule ${ }^{2}$, H.M.N. Ifebi ${ }^{1}$, C.C. Ezea ${ }^{1 *}$, C.C. Onwuzuligbo ${ }^{1}$, F.C. Anowi ${ }^{1}$, C. J. Ike ${ }^{3}$, H. C. Nedum ${ }^{1}$
}

\begin{abstract}
Background: Pharmacognostic standards and toxicological studies of the leaf of $S$. siamea were carried out.

Objectives: To determine the quantitative phytochemical constituents present, pharmacognostic standards and toxicological effect of the methanol leaf extract and fractions of S. siamea.

Methodology: Fresh leaves of S. siamea were collected, dried, pulverizes to powder and subjected to pharmacognostic and quantitative phytochemical analysis. The pulverized leaves were cold macerated in methanol for three days with intermittent shaking and exchange of fresh solvent every 24 hours (aliquot extraction). Fractionation was done using n-hexane, ethylacetate and butanol. Chromatographic analysis of the methanol extract and fractions were obtained using standard methods. The methanol extract and fractions where screened for phytochemical constituents and toxicological effects using standard methods. Acute toxicity $\left(L_{50}\right)$ of the extract was determined using Lorke's method.
\end{abstract}

Results: Macroscopic and microscopic examinatios revealed acute apex, pinnate venation and dialytic stomata, trichomes respectively. Phytochemical screening of the extract and fractions revealed the presence of flavonoids, alkaloids, saponins, tannins etc. Proximate analysis of $S$. siamea revealed moisture content of $5.50 \%$, total ash value of $15.00 \%$, watersoluble ash of $2.00 \%$ etc. The $\mathrm{LD}_{50}$ was found to be $>5000$ $\mathrm{mg} / \mathrm{kg}$. An increase in ALT, AST, and ALP when metanol extract and fractions were administered were not statistically different from the control group, indicating no hepatotoxic potential. An increase in PCV, $\mathrm{Hb}$, and RBC when methanol extract and fractions were administered were not statistically different from control group. The non-significant decrease in the levels of ALP, ALT and AST indicates that the extract has a possible

\footnotetext{
${ }^{1}$ Department of Pharmacognosy and Traditional Medicine, Faculty of Pharmaceutical Sciences, Nnamdi Azikiwe University, Awka, Anambra State, Nigeria.

${ }^{2}$ Department of Pharmaceutical Chemistry and Medicinal Chemistry, Faculty of Pharmaceutical Sciences, Nnamdi Azikiwe University, Awka, Anambra State, Nigeria.

${ }^{3}$ Department of Pharmacology and Toxicology, Faculty of Pharmaceutical Sciences, Nnamdi Azikiwe University, Awka, Anambra State, Nigeria.

Corresponding Author: Ezea, Charity Chinasa; Department of Pharmacognosy and Traditional Medicine, Faculty of Pharmaceutical Sciences, Nnamdi Azikiwe University, Awka, 422001, Anambra State, Nigeria. Tel: +234 8060375668, E-mail: cc.ezea@unizik.edu.ng
}

hepatoprotective effect. The non-significant decrease in the levels of RBC, $\mathrm{Hb}$ and PCV indicates that the extract does not affect the hematopoietic system when administered orally and at the doses used in the study.

Conclusions: Specific standards obtained from the study may be compiled into a monograph of S. siemea plant that may constitute in the herbal pharmacopeia.

Keywords: Pharmacognostic standardization, Senna Siamea leaf, Toxicological effect.

How to cite this article: Surname Initials. Article title. Int. J. Pharm. Edu. Res. 2021;3(1):25-36.

\section{Source of support: Nil}

Conflict of interest: None

\section{INTRODUCTION}

\section{Standardization of Herbal Medicine}

Standardization of drugs is the process of establishing or prescribing a set of peculiar identities, specific characteristics which are generally unique and of ushered qualities. Pharmacognostic standardization of a drug is a process involving a series of a laboratory experiment which reveal and assemble a set of inherent peculiar characteristics such as, constant parameter, definite qualitative and quantitative values or specific and unique features on the bases of which similar herbal medicine, claimed to be the same can be compared for the purpose of authenticity, efficacy, purity, reproducibility and overall quality assurance. Uniformity of quality is promoted by the use of standards which are numerical qualities by which the quality of commodities may be assessed (Inya-Agha, 2006). Specific standards obtained through experimentation may be compiled into a monograph of the particular medicinal plant. A monograph of selected of a medicinal plant can be assembled together to constitute a herbal pharmacopeia. Herbal pharmacopeia carries an assurance of data for monitoring safety, efficacy, and reproducibility. The pharmacopeia essentially provides a parameter for any national drug regulatory requirements or dossiers (Inya - Agha, 2006).

Analytical Thin-layer Chromatography (TLC): Analytical ThinLayer Chromatography (TLC) is best on the quantitative 
measurement of constituents in a mixture. TLC is a universal tool required to determine other chromatographic systems' direction, apart from serving as a useful analytical and isolation instrument. Analytical TLC is important in choosing the type of adsorbent and solvent systems for further work. Solvents that achieve good separation on TLC plates indicate the type of solvent for column chromatography, chromatotrone, flash chromatography, and so on, though the priority of solvents eventually used might be slightly less than that of TLC (Evans, 2009).

Analytical Standards involve determining the purity, quality and evaluation of the physical properties or characteristics of the active constituents. It is virtually impossible to avoid some naturally occurring inorganic or organic contaminants while collecting crude drugs from the field. The purity depends upon the absence of foreign matter, whether organic or inorganic, while the quality refers essentially to the drugs' active constituents' concentration. The principal inorganic matter found in crude drugs is sand or other inorganic constituents in the soil. The most common foreign organic matter consists of parts of the plant that are not officially included in the description, or it may be the parts of the neighboring plants of another species. Some of the other contaminants include insect, mold, animal excreta etc (Ewuram, 2009).

\section{Toxicology Testing}

Toxicology testing, also known as safety assessment, or toxicity testing, is conducted to determine the degree to which a substance can damage a living or non-living organisms or the determination of potential hazards a test substance may likely produce and the characterization of its action, most of the toxicity testing is carried out on experimental animals. The essence of toxicity testing is not just to check how safe a test substance is; but to characterize the possible toxic effects it can produce (Cunny et al., 1997).

\section{Importance of Toxicity Studies}

- To establish a dose-response curve.

- To ensure the safety of new chemicals for use as, drugs or food additives before they are

- Registered for general use.

- To establish the mode of action or mechanism for a toxic effect that may have been seen in other studies.

- To validate new methods of testing or investigation, particularly those conducted in vitro rather than in animals.

Toxicity testing plays a crucial role in ascertaining the toxic effect and characterization of test substances. Toxicity obtained in animal studies occurs with similar incidence and severity in humans. The use of animals in toxicity testing is most likely to continue for the foreseeable future because of their benefits in examining a whole functioning organism (Woolley, 2008).

S. siamea, (English- kassod tree or yellow cassia, Yoruba- Ewe kasia, Benin- cassiantin, kassia) is a tropical tree, native to Southeast Asia, India, and Sri Lanka. This plant is a shrub, $10-12 \mathrm{~m}$ tall, occasionally reaching 20 $\mathrm{m}$ and is widely grown throughout tropical Africa. It belongs to the Caesalpiniaceae Family (El-mahmood and Doughari, 2008; Esievo et al., 2016). S. siamea has been used traditionally in the management of constipation, diabetes, insomnia (Tripathi and Gupta, 1991), hypertension, asthma, typhoid fever and diuresis (Gills, 1992). Leaves and bark of the plant were used locally as antimalarial medication (Lose et al., 2000; Ogunkunle and Ladejobi, 2006). The leaf is also used in the treatment of anaemia and fever (Sati et al., 2010). Antimalarial, anti-diabetic, (Odason and Kolawole, 2007), antitumor or anticancer, anti-inflammatory, (Kupradinun et al., 2011; Nsonde Ntandou et al., 2010), laxative (Morales et al., 2009), analgesic, antipyretic, anxiolytic, antidepressant and sedative properties (Wongwitdecha, 2007) has been reported of $S$. siamea. With the numerous ethnomedicinal uses of S. siemea plant, we aim to evaluate the toxicity profile of the methanol leaf extract and fractions to be added in the plant's monograph.

\section{MATERIALS AND METHODS}

\section{Materials}

\section{Plant Collection and Identification}

Fresh leaves of S. siamea was collected from Agulu and authenticated by Mr. Alfred Ozioko at the International Centre for Ethnomedicine and Drug Development (INTERCEDD), Nsukka, Enugu State, Nigeria. A voucher specimen was deposited in the herbarium of the Department of Pharmacognosy and Traditional Medicine, Nnamdi Azikiwe University, Awka with voucher specimen number: PCG 566/A/065

\section{Reagents and Solvents}

Methanol (JHD, China), n-Hexane (JHD, China), Ethylacetate (JHD, China), Butanol (JHD, China), Giemsa stain (Ferntec, Nigeria), Distilled water.

\section{Equipment}

Electronic microscope (Olympus, China), Microscope slides (Vitex, Nigeria), Water bath (Serological, England), capillary tube (Vitex, Nigeria), Electronic Weighing Balance (Ahaus, Poland), Beakers (pyrex).

\section{Experimental Animals}

Swiss albino mice (22 - $30 \mathrm{~g}$ ) were procured from the Animal House of the Department of Pharmacology and 
Toxicology Nnamdi Azikiwe University. The animals were fed with pelletized feed (vital feeds, Nigeria) and water ad libitum. The animals' housing was done in standard cages in the animal house of the Department of Pharmacology and Toxicity, Nnamdi Azikiwe University, Awka. They were allowed to acclimatize for 1 week before commencement of study. The handling of the animals was carried out according to the standard guideline (OECD, 1987).

\section{Methods}

\section{Extraction}

The plant materials were cleaned, air-dried at room temperature for one month and pulverized, $1800 \mathrm{~g}$ of the pulverized leaves were cold macerated in methanol with intermittent shaking and exchange of fresh solvent every $24 \mathrm{hrs}$ (aliquot extraction) for $72 \mathrm{hrs}$. The resulting solution was pooled and filtered. The filterate was concentrated using a rotary vacuum evaporator at $40^{\circ} \mathrm{C}$. Thereafter, it dried to a constant weight in a water bath at a temperature of $40^{\circ} \mathrm{C}$ to obtain methanol extract.

\section{Extractive Yield}

This was carried out using the methods according to Onwuka, 2005. Extracts of known volumes were evaporated to dryness in a tarred glass crucible. The weight of each extract was determined by finding the difference between the empty crucible weight and the crucible containing the semi-solid marc. The weight per $\mathrm{mL}$ was then calculated from the values obtained.

\section{Liquid-Liquid Fractionation}

The pre-concentrated filtrate of the methanol extract was subjected to liquid-liquid partitioning successively with $2.5 \mathrm{~L}$ of $\mathrm{n}$-hexane, ethyl acetate, and butanol using a separating funnel to obtain the n-hexane, ethyl acetate, and butanol soluble fractions, respectively. All fractions were dried using a rotary evaporator.

\section{Macroscopic Examination of the Plant Materials}

\section{Macroscopic Examination of the Leaves}

The leaves were examined with unaided senses (naked eyes, nose, and hands). The color is examined using an untreated sample under diffuse daylight. Artificial light source similar to those of daylight was also used occasionally. The macroscopic characters of the leaves, which include types of margin, venation, base apex, midrib, size, etc. were observed and noted. The organoleptic properties such as color, texture, odor, and taste of the plant material were also observed and noted (Evans, 2009).

\section{Microscopic Examination}

\section{Qualitative Microscopy}

The powdered leaf sample was placed on a slide, two drops of chloral hydrate solution were added to moisten the powder and act as a clearing agent. The slide was passed across the flame of a burnsen burner repeatedly until bubbles occurred. It was allowed to cool, the slide was covered with glycerin followed with coverslip, and was viewed under the microscope. The microscopic characters were observed and noted (Evans, 2009).

\section{Quantitative Microscopy}

\section{Palisade Ratio}

The powdered leaves were cleared by boiling with chloral hydrate solution, mounted and examined with a $4 \mathrm{~mm}$ objective microscope. A camera lucida was employed so that the epidermal cells and the palisade cells lying below them. First, many groups of each of four epidermal cells were traced, and their outlines were inked to make them more conspicuous. The palisade cells lying beneath each group were then focused and traced. The palisade cells in each group are included in the count, which are more than half-covered by the epidermal cells; the value obtained divided by four gives the group's palisade. The range of several groups from different particles was recorded (Evans, 2009).

\section{Stomatal Number}

Fresh leaves were used, and an appropriate $50 \%$ gelatin was liquefied on a water bath and smeared on a hot slide. The fresh leaves were added, the slide inverted and cooled under a tap and after 15-30 min, the specimen was stripped off. The imprint on the gelatin gave a clear outline of epidermal cells, stomata, and fibers (Evans, 2009).

\section{Stomatal Index}

Pieces of leaf (not extreme margin or midrib) were suitably cleared and mounted. The lower surface was examined by means of a microscope with a $4 \mathrm{~mm}$ objective and an eye-piece containing a $5 \mathrm{~mm}^{2}$ micrometer disc. Counts were made of the numbers of epidermal cells and stomata (the two guard cells being considered one unit) within the square grid, a cell was counted if at least half of its areas lie within the grid. Successive adjacent fields were examined until about 400 cells were counted and the stomatal index value calculated from these figures. The stomatal index was determined for both surfaces (Evans, 2009).

\section{Vein-islet Number}

The leaves were cleared by boiling in chloral hydrate 
solution in a test tube and placed in a boiling water bath. The camera lucida was set up, and a stage micrometer was used to divide the paper into squares of $1 \mathrm{~mm}^{2}$ using a $16 \mathrm{~mm}$ objective. The cleared preparation then replaces the stage micrometer and the veins were traced in four contiguous squares, in a rectangle of $1 \mathrm{~mm} \times 4 \mathrm{~mm}$. the vein-islet is numbered on the tracing (Evans, 2009).

\section{Veinlet Termination Number}

Pieces of the leaves were soaked in water and then were treated with sodium hypochlorite and $10 \%$ hydrochloric acid. It was boiled with chloral hydrate solution for 5 minutes to clear. A stage micrometer was attached to the microscope, and a tracing paper was placed above the drawing board. The stage micrometer was used to divide the paper into $1 \mathrm{~mm}^{2}$. A camera lucida was set up, and the leaf was mounted and examined. The veinlet was traced in four contiguous squares in a rectangle of $1 \mathrm{~mm} \times 4 \mathrm{~mm}$, and each veinlet was numbered and noted (Evans, 2009).

\section{Transverse section of the Leaf}

With the aid of the sledge microtome, a thin transverse section of the leaf was cleared in a solution of chloral hydrate, after which it was stained with $1 \%$ phloroglucinol in hydrochloric acid, covered with glycerin and coverslip and viewed under the microscope. In a second slide, the cleared thin section was stained with iodine, covered with glycerin and cover slip and viewed under the microscope. The distribution of tissues and details of individual cells' structures were photographed and drawn with the aid of motic image plus 2.0 digital camera (Evans, 2009).

\section{Determination of Analytical Standards}

\section{Determination of Ash Values}

The total ash, acid insoluble ash, water-insoluble extractive value and water soluble ash values were carried out using standard methods as described by Odoh et al., 2011.

\section{a) Total ash values}

A tarred nickel crucible was placed in muffle furnace for about 15 minutes at $35^{\circ} \mathrm{C}$, cooled in a desiccator for about one hour and the crucible was weighed $\left(\mathrm{W}_{1}\right)$, $3.0 \mathrm{~g}\left(\mathrm{~W}_{2}\right)$ of the powdered material was placed into the nickel crucible and heated gently until all the moisture has been driven off and the plant material was completely charred. The heat was slowly increased until the carbon has vaporized and the residue was free from carbon at $650{ }^{\circ} \mathrm{C}$, and the sample turns grey (white ash). The crucible was removed with a crucible tong, cooled in a desiccator, and reweighed $\left(\mathrm{W}_{3}\right)$. The percentage ash content was determined by the relationship;
Percentage Ash $=\frac{\text { final weight of crucible }\left(W_{3}\right)-\text { initial weight of crucible }\left(W_{1}\right)}{\text { weight of sample }\left(W_{2}\right)-\text { iinitial weight of crucible }\left(W_{1}\right)} \times 100$

...Eqn1

\section{b) Water-soluble ash value}

A nickel crucible was ignited to a constant weight at $450{ }^{\circ} \mathrm{C}$, cooled, and then weighed $\left(\mathrm{W}_{1}\right) .3 .0 \mathrm{~g}\left(\mathrm{~W}_{2}\right)$ of the material was placed and spread over the bottom of the crucible and then reweighed. The plant material was incinerated at $450^{\circ} \mathrm{C}$ by gradually increasing the heat until it was free from carbon. The crucible was cooled in a desiccator and then reweighed. The contents of the crucible were transferred into a beaker; $5 \mathrm{~mL}$ of water was added into the beaker and then boiled for 5 minutes. The mixture was filtered through an ashless filter paper, and both the residue and the filter paper were dried in an oven. The ashless filter paper containing the residue was compressed into the crucible and was subjected to heat until the ashless paper was eliminated. The crucible was reweighed $\left(\mathrm{W}_{3}\right)$, and the differences were noted with the formula;

\section{c) Acid-insoluble ash value}

The ash obtained above was transferred into a beaker containing $25 \mathrm{~mL}$ of dilute hydrochloric acid and was boiled for 5 minutes. The insoluble matter was collected in a sintered crucible and an ashless filter paper. The beaker and crucible were washed repeatedly through the filter paper with hot water until it was free from acid. It was ignited to constant weight at about $500{ }^{\circ} \mathrm{C}$.

\section{d) Water-soluble extractive value}

About $5.0 \mathrm{~g}$ of the material was weighed accurately and placed in a stoppered conical flask. A total of 100 $\mathrm{mL}$ of chloroform-water was added, and the stopper of the conical flask was replaced firmly. The flask and its content were shaken mechanically for about 6 hours and was allowed to macerate for another 18 hours and then filtered. The filtrate was collected and evaporated to dryness, and then the residue was dried to a constant weight of $105^{\circ} \mathrm{C}$.

\section{Determination of Moisture Content}

A preheated, tarred porcelain crucible was weighed, and its weight with lid was recorded $\left(W_{1}\right)$. A spatula full of the dried sample was introduced into the crucible and reweighed $\left(\mathrm{W}_{2}\right)$. The sample was heated in an oven at the temperature of $65^{\circ} \mathrm{C}$ for 12 hours, at intervals of $6,3,2,1$, hours, until constant weight $\left(W_{3}\right)$ was noted. The percentage of moisture was calculated from the relationship (Onwuka, 2005). Percentage moisture content $=\frac{\text { Weight of sample in crucible }\left(W_{2}\right)-\text { Constant weight }\left(W_{3}\right)}{\text { Weight of sample in crucible }\left(W_{2}\right)-\text { Weight of crucible }\left(W_{1}\right)} \times 100$ 
Where

$$
\begin{aligned}
& W_{2}-W_{1}=\text { Weight of sample } \\
& W_{2}-W_{3}=\text { Weight of moisture }
\end{aligned}
$$

\section{Analytical Thin-layer Chromatography (TLC)}

TLC plates were prepared by coating the plates (10 by 20 $\mathrm{cm})$ with silica-gel $\mathrm{G}_{60} \mathrm{~F}_{254}$, with a binder's help using a suitable spreader. The TLC plates (0.25 mm layer) were reactivated at $100{ }^{\circ} \mathrm{C}$ for $5 \mathrm{mins}$ in an oven before use. $\mathrm{A}$ slight line $(1.5 \mathrm{~cm})$ from each plate's base was carefully marked; a drop of the samples was placed along the line centered as much as possible. These applications were allowed to dry up, and that was repeated twice (i.e., 2 applications each). The plates were placed in a $1 \mathrm{~cm}$ layer of a solvent system (Chloroform: methanol: ammonium hydroxide (5:4:1), chloroform: methanol (1:1), and chloroform: ethanol (1:1)) at the bottom of the developing chamber and the lid was placed over. Inside the developing chamber (chromatographic tank), the chromatogram was developed. After one hour (1hr), the plates were removed from the tank, and then solvents were allowed to evaporate. The major spots were located using an iodine chamber as the detecting agent. From the chromatograms developed, the retardation factors $\left(R_{1}-\right.$ values $)$ of the major spots were calculated using the formula;

$$
R_{f}=\frac{\text { Distance moved from origin by a solute }}{\text { Distance moved from origin by solvent front }} \times 100
$$

\section{Phytochemical Analysis}

The extract was tested for the presence of carbohydrates, alkaloids, reducing sugar, glycosides, saponins, tannins, resins, flavonoids, proteins, steroids, terpenoids, fats, and oils, according to Evans (2009), Harbourne (1973).

\section{Quantitative Phytochemical Analysis}

\section{a) Determination of Alkaloid}

A $5 \mathrm{gm}$ powdered S. siamea leaves were added into a $250 \mathrm{~mL}$ beaker; $200 \mathrm{~mL}$ of $10 \%$ acetic acid was added into a beaker, covered it, and allowed to stand for 4 hours. Content in the beaker was filtered and the extract was concentrated on a water bath to 1-quarter of the original volume. Concentrated ammonium hydroxide was added drop-wise to the extract till there is a presence of precipitate. This solution was allowed to settle. The precipitate then collected, washed with dilute ammonium hydroxide and filtered (Harborne, 1973) dried, and weighed.

\section{b) Determination of Flavonoid.}

A portion of the extract was dissolved in methanol and the volume of the solution was made up to $3 \mathrm{~mL}$. Then
$0.1 \mathrm{~mL} \mathrm{AICL}_{3}(10 \%), 0.1 \mathrm{~mL} \mathrm{Na}-\mathrm{K}$ tartarate, and $2.8 \mathrm{~mL}$ distilled water were added sequentially. The resulting solution was vigorously shaken. The absorbance was measured at $415 \mathrm{~nm}$ after $30 \mathrm{~min}$ of incubation. A standard calibration plot was done at $415 \mathrm{~nm}$ using known concentrations of quercetin (Sigma, Germany). The concentrations of flavonoids in the test samples were calculated from the plot and expressed in percentage $(\%$ $\mathrm{w} / \mathrm{w}$ ) as mg quercetin equivalent /g of sample (Chang et al., 2002).

\section{c) Determination of Tannins}

About $500 \mathrm{mg}$ of $S$. siamea powdered leaves was weighed into a $50 \mathrm{~mL}$ plastic bottle. $50 \mathrm{~mL}$ of distilled water was added and shaken for $1 \mathrm{hr}$ in a mechanical shaker. This was filtered into a $50 \mathrm{~mL}$ volumetric flask and made up to the mark. Then, $5 \mathrm{~mL}$ of the filtrate was pipetted out into a test tube and mixed with $2 \mathrm{~mL}$ of $0.1 \mathrm{M} \mathrm{FeCl}$ in $0.1 \mathrm{~N} \mathrm{HCL}$ and $0.008 \mathrm{M}$ potassium ferrocyanide. The absorbance was measured at $120 \mathrm{~nm}$ within 10 minutes.

\section{d) Determination of Saponins}

About $10 \mathrm{~g}$ of $S$. siamea leaf powder was put into a conical flask and then $50 \mathrm{~mL}$ of $20 \%$ aqueous ethanol was added. The sample was heated with continuous stirring at $55^{\circ} \mathrm{C}$ over a hot water bath for 4 hours. This mixture was filtered and the remaining residue re-extracted with another $100 \mathrm{~mL} 20 \%$ ethanol. Both the extract combined and reduced up to $40 \mathrm{~mL}$ over water bath at $90^{\circ} \mathrm{C}$. The concentrate obtained was transferred into a $250 \mathrm{~mL}$ separating funnel, and $10 \mathrm{~mL}$ of diethyl ether was added and shaken vigorously. In separating funnel, two separate layers were observed out of which aqueous layer was recovered, and the ether layer was discarded. The process of purification was repeated. To the aqueous extract $30 \mathrm{~mL}$ of $\mathrm{n}$ - butanol was added. A combined $\mathrm{n}$ - butanol extracts were washed twice with $10 \mathrm{~mL}$ of $5 \%$ aqueous sodium chloride. The remaining solution was heated in a water bath. After evaporation, the sample obtained were dried in oven to the constant weight and the saponin percentage was calculated (Obadoni and Ochuko, 2001).

\section{Pharmacological Evaluation}

\section{Acute-toxicity and Lethality $\left(L D_{50}\right)$ Test}

The $\mathrm{LD}_{50}$ determination was carried out according to the method of Lorke (1983). A total of 13 mice were used. The study was carried out in two phases. In the first phase, 9 mice of weight $22-30 \mathrm{~g}$ were grouped into 3 groups of 3 mice per group. Group 1 received $10 \mathrm{mg} / \mathrm{kg}$ crude extract, while group 2 were administered $100 \mathrm{mg} /$ $\mathrm{kg}$ crude extract. The last group received $1000 \mathrm{mg} / \mathrm{kg}$ of crude extract per oral (PO). The animals were constantly 
monitored for 2 hours, intermittently for the next 6 hours, and after 24 hours for behavioral changes and mortality. From the result of phase 1 , the second phase was carried out. In the second phase, 4 mice were used. The mice were grouped into 4 groups of 1 mouse per group. Group 1 received $2000 \mathrm{mg} / \mathrm{kg}$ crude extract while group 2 was administered $3000 \mathrm{mg} / \mathrm{kg}$ crude extract. Group 3 received $4000 \mathrm{mg} / \mathrm{kg}$ of the crude extract and the last group received $5000 \mathrm{mg} / \mathrm{kg}$. The animals were also monitored for behavioral changes and mortality.

\section{Biochemical Studies}

The biochemical study was carried out as described by Baheti et al., (2006). Blood was collected in nonheparinised tubes. The blood sample was centrifuged at the speed of $4000 \mathrm{rpm}$ at room temperature for 10 min and the supernatant separated and used for the following tests:

\section{Procedure (Teco diagnostics)}

\section{Alkaline phosphate $(A L P)$}

Fresh tubes were labeled "standard", "sample," and "blank," respectively. Approximately $0.5 \mathrm{~mL}$ of alkaline phosphatase substrate (in the kit) was dispensed in all the tubes and was equilibrated to $37^{\circ} \mathrm{C}$ for 3 minutes using a water bath. To the standard, $5 \mu \mathrm{g}$ of the standard reagent (in the kit) was dispensed; to sample, $50 \mu \mathrm{g}$ of the sample are dispensed and to the blank $50 \mu \mathrm{g}$ of de-ionized water was dispensed. The whole tubes were mixed gently; incubated for $10 \mathrm{~min}$ at $37 \mathrm{o} \mathrm{C}$. Then, $2.5 \mathrm{~mL}$ of alkaline phosphatase color developer (in the kit) was dispensed in all the tubes and mixed properly. The absorbance was read at $600 \mathrm{~nm}$ using a spectrophotometer. Then the concentration of ALP was calculated as follow:

\section{Alanin aminotransferase (ALT)}

$R_{1}$ and $R_{2}$ (in the kit) were mixed at the ratio of 5:1 and was termed "working reagent".Fresh tube was labeled "sample" and "blank". To the tubes, $1.0 \mathrm{~mL}$ of working reagent was dispenses and incubated for $5 \mathrm{~min}$ at 37 ${ }^{\circ} \mathrm{C}$. To the samples, $100 \mu \mathrm{l}$ of each sample was added respectively; and to the blank, $100 \mu \mathrm{l}$ of distilled water was added. The absorbance was read at $1 \mathrm{~min}$ and at 3 mins using a spectrophotometer at $340 \mathrm{~nm}$. Then the ALT concentration calculated as follow;

\section{Aspartate aminotransferase (AST)}

R1 and R2 (in the kit) was mixed at the ratio of 1:5 and was termed "working reagent". Fresh tube was labeled "sample" and "blank." To the tubes, $1.0 \mathrm{~mL}$ of working reagent was dispenses and incubated for 5 minutes at $37^{\circ} \mathrm{C}$. To the samples, $100 \mu \mathrm{l}$ of each sample was added respectively; and to the blank, $100 \mu \mathrm{l}$ of distilled water was added. The absorbance was read at $1 \mathrm{~min}$ and at 3 mins using a spectrophotometer at $340 \mathrm{~nm}$. Then the AST concentration calculated as follow;

\section{Heamatological Studies}

\section{Estimation of Packed Cell Volume}

Capillary tube was placed in the EDTA container containing the Blood sample, the blood sample was allowed to fill up to $70 \%$ of the capillary tube, then one end of the tube was sealed with plasticine. The tubes were placed in the microhematocrit centrifuge making sure the sealed end was placed against the rubber gasket. The centrifuge was closed, put on and allowed to centrifuge at $1200 \mathrm{rmp}$ for 10 minutes, and the value was read using micro hematocrit reader.

\section{Estimation of haemoglobin (Sahli's method)}

The dilution tube in Sahli's apparatus was sealed to mark 10 with fresh 0.1 N HCL. Blood was sucked up to $20 \mathrm{~mm}^{3}$ of the pipette. Then the blood was blown into the HCL and was mixed well and then allowed to stand for 5 minutes. Then the distilled water was added drop by drop from a pipette stirring with a glass rod after each drop until the colour was just like that of the standard. Distilled water was added again until the color became paler than that of the standard. The average of the two readings were taken, the values were expressed in $\mathrm{mg} / \mathrm{dl}$.

\section{Statistical analysis}

The data was analyzed using Dunnett multiple comparison test in one way ANOVA. Results were tabulated and presented as mean \pm standard error of mean and by frequency distribution on a bar chart. p-values of 0.05 or less were considered statistically significant. All of the data were expressed as mean \pm SEM (standard error of mean) and $n$ represents the number of replicates in an experiment.

\section{RESULTS AND DISCUSSION}

\section{Extraction and Fractionation}

The extraction process yielded $360 \mathrm{~g}$ of the crude extract (CE), and the yield of the fractionation is presented in Table 1.

Table 1: Yi .....Eqn1 elds obtained from the crude extract and fractions of $S$. siamea

\begin{tabular}{ll}
\hline Extract/Fractions & Yield $(g)$ \\
\hline Crude extract & $360(20 \% \mathrm{w} / \mathrm{w})$ \\
$\mathrm{N}-$ Hexane fraction & $0.24(0.36 \% \mathrm{w} / \mathrm{w})$ \\
Ethyl acetate fraction & $5.01(7.59 \% \mathrm{w} / \mathrm{w})$ \\
Butanol fraction & $15.78(24 \% \mathrm{w} / \mathrm{w})$ \\
\hline
\end{tabular}




\section{Macroscopic Examinations of the Whole Leaves}

The result of the macroscopic examination of the whole leaves of Sienna siamea ia as shown in Table 2.

\section{Microscopic Examination of the Leaf of S. siamea}

The result of the microscopic examination of S. siamea was carried out to show the description of different microscopic character of the plant such as stomata type, trichomes calcium oxalate. Quantitative leaf constant such as stomatal number, stomatal index, palisade ratio, vein islet and vein termination number were also evaluated. The microscopic examination of the whole leaves of Sienna siamea as shown in Table 3 - 4 and Figs. $1-6$.

\section{Proximate Analysis of the Leaf}

The evaluation of the proximate analysis is useful in determining the purity and quality of crude drug. The

Table 2: Macroscopic examination of Senna siamea

\begin{tabular}{ll}
\hline Macroscopic examination & Observations \\
\hline Colour & Dark green \\
Margin & Entire margin lamina \\
Apex & Acute \\
Inflorescence & Racemes at the end of the branches \\
Venation & Pinnate \\
Base & Asymmetric base \\
Size & Up-right, up to 3ft \\
Texture & Papery texture \\
Surface & Glabrous \\
Odour & Characteristic \\
Taste & Unpleasant \\
\hline
\end{tabular}

values of percentage composition shown are mean \pm SEM (Table 5).

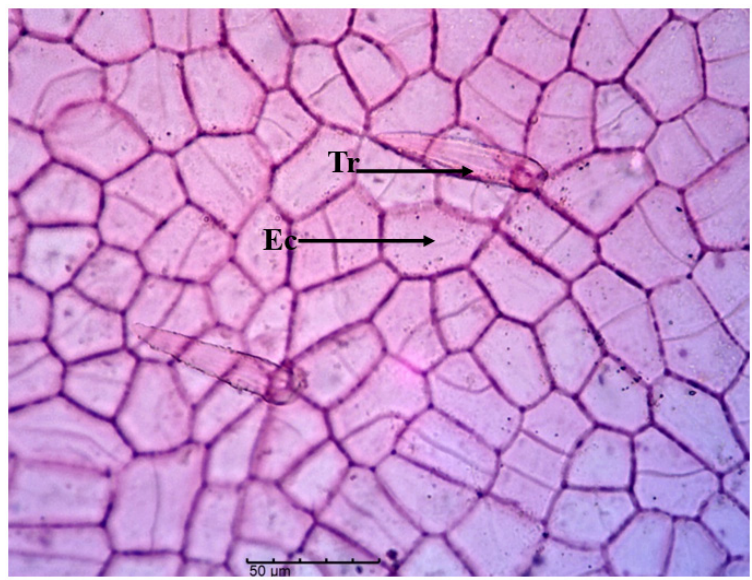

$\mathrm{X} 400$

Figure 1: Adaxial (upper) epidermal surface of the leaf of $S$. siamea showing unicellular trichomes $(\mathrm{Tr})$ and polygonal epidermal cells with straigth anticlinal cell walls (Ec)

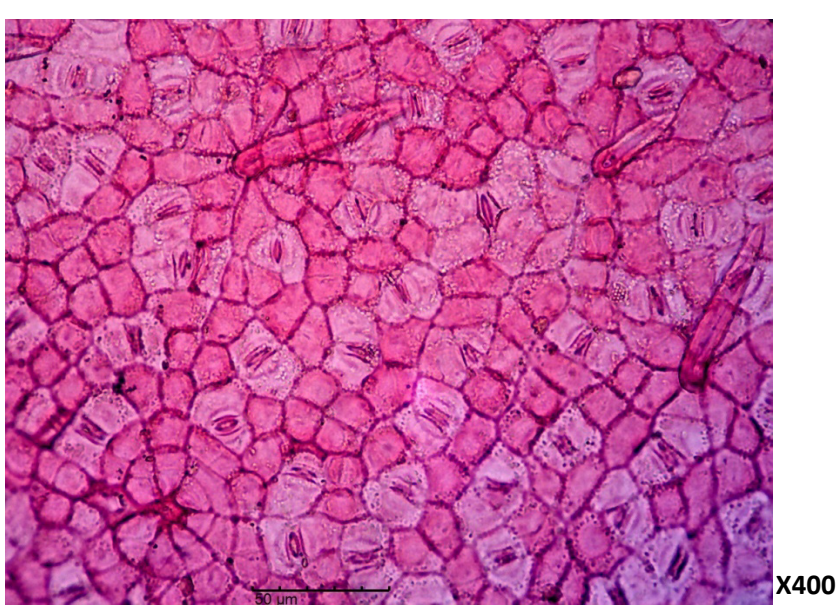

Figure 2: $\mathrm{Ab}$ (lower) epidermal surface of the leaf of $S$. siamea showing unicellular trichomes ( $\mathrm{Tr}$ ), polygonal epidermal cells with straigth anticlinal cell walls (Ec) and paracytic stomata (St)

Table 3: Microscopy result of the leaf of Senna siamea

\begin{tabular}{lll}
\hline Parameter & Adaxial (upper) surface & Abaxial (lower) surface \\
\hline $\begin{array}{l}\text { Leaf type } \\
\text { Epidermal cell type }\end{array}$ & $\begin{array}{l}\text { The leaf is hypostomatic (stomata only occur on the abaxial surface of the leaf) } \\
\text { Polygonal in shape with straight anticlinal cell } \\
\text { walls }\end{array}$ & $\begin{array}{l}\text { Polygonal in shape with straight anticlinal cell walls } \\
\text { Stomata type }\end{array}$ \\
NIL & $\begin{array}{l}\text { Paracytic (two subsidiary cells occur in parallel } \\
\text { position to the guard cells) }\end{array}$ \\
Trichome type & Present: Simple and Unicellular & Present: Simple and Unicellular \\
Stomata frequency $\left(\mathrm{mm}^{-2}\right)$ & NIL & $352.94 \pm 7.67$ \\
Stomata index $(\%)$ & NIL & $30.14 \pm 0.61$ \\
Stomata length $(\mu \mathrm{m})$ & NIL & $15.15 \pm 0.48$ \\
Stomata width $(\mu \mathrm{m})$ & NIL & $11.86 \pm 0.46$ \\
Stomata size $\left(\mu \mathrm{m}^{2}\right)$ & NIL & $179.97 \pm 10.18$ \\
Trichome frequency $\left(\mathrm{mm}^{-2}\right)$ & $10.59 \pm 1.18$ & $21.18 \pm 1.44$ \\
Trichome index $(\%)$ & $1.88 \pm 0.21$ & $2.53 \pm 0.19$ \\
Vein islet number & $18.8 \pm 2.73$ & \\
Veinlet termination number & $17.8 \pm 1.83$ & \\
Palisade ratio & $4.8 \pm 0.37$ & \\
\hline All & &
\end{tabular}

All values are expressed as Mean \pm SEM, $n=3$ 


\begin{tabular}{|c|c|}
\hline Lignin & Present \\
\hline Tannins & Present \\
\hline Mucilage & Present \\
\hline Calcium oxalate & Present (prism shape) \\
\hline Starch & Present \\
\hline \multicolumn{2}{|c|}{ Table 5: Proximate analysis of $S$ siamea leaf } \\
\hline Analytical standards & $\%$ composition \\
\hline Total ash & 10.6 \\
\hline Water soluble ash & 2.0 \\
\hline Acid insoluble ash & 5.1 \\
\hline Water soluble extractive value & 8.2 \\
\hline Alcohol soluble extractive value & 6.1 \\
\hline Moisture content & 5.5 \\
\hline
\end{tabular}

Values of \% composition shown

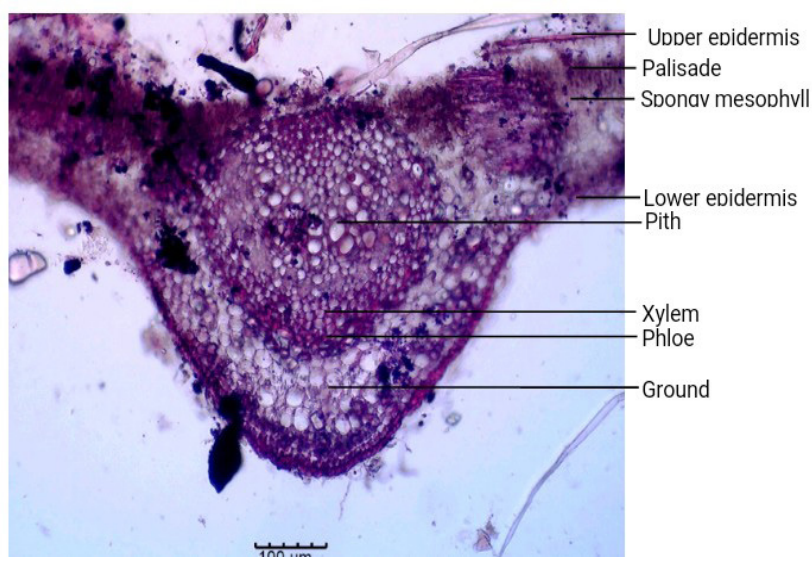

Figure 3: Transverse section of S. siamea leaf.

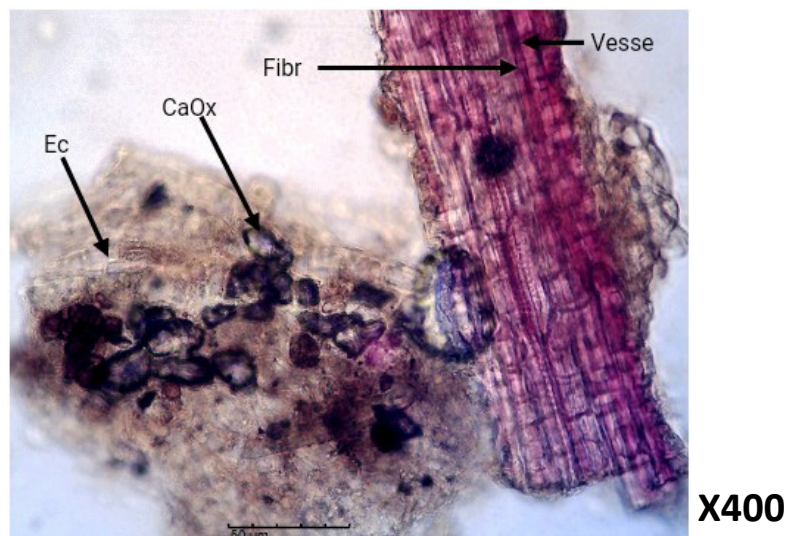

Figure 4: Micrograph of the leaf powder of $S$. siamea showing lignified tissues (Fibre and vessel), calcium oxalate crystal $(\mathrm{CaOx})$ and epidermal cell (Ec)

\section{Chromatographic Fingerprint}

The result of the chromatographic fingerprint of the methanol of S. siamea is presented in Table 6.

\section{Phytochemical Analysis}

\section{Qualitative Phytochemical Analysis}

The crude extract and the fractions revealed the presence of flavonoids, saponins, tannins, etc while they vary

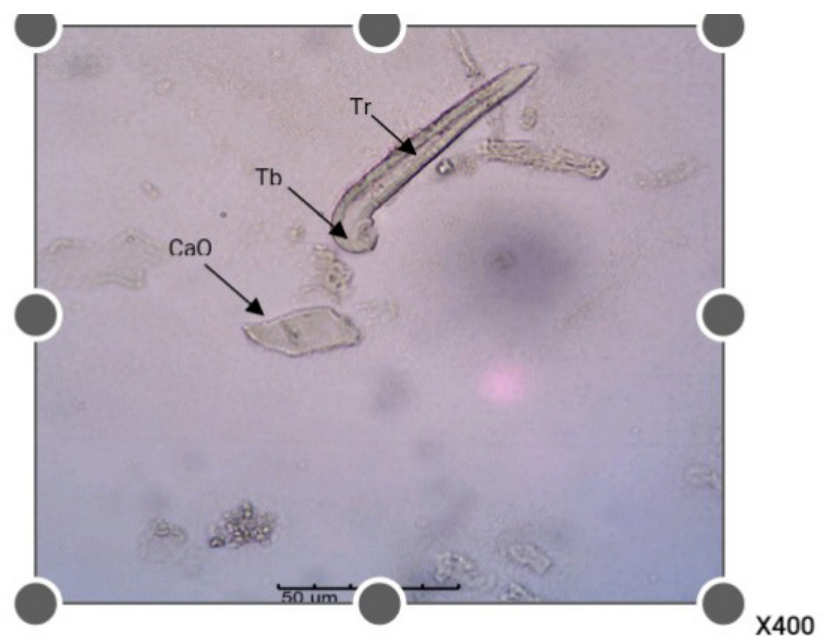

Figure 5: Micrograph of the powder of $S$. siamea showing unicellular trichome $(\mathrm{Tr})$ with round base $(\mathrm{Tb})$ and prism of calcium oxalate crystal $(\mathrm{CaOx})$

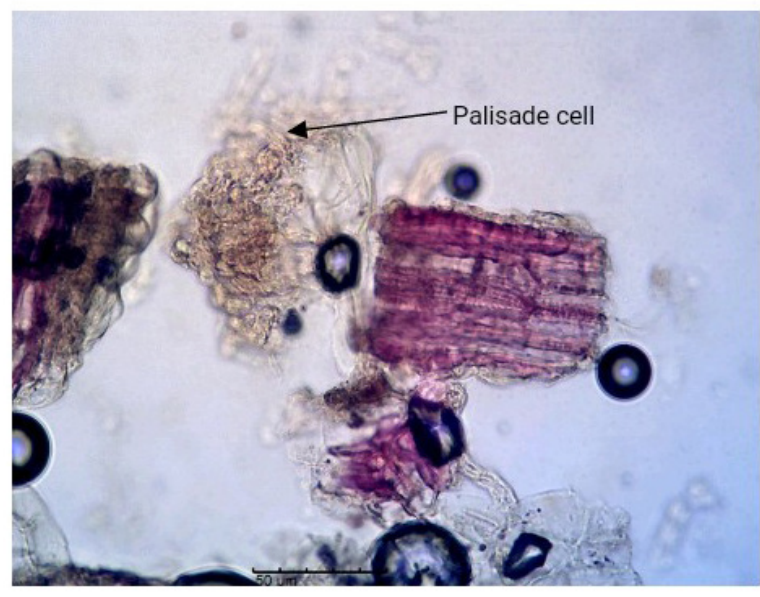

X400

Figure 6: Micrograph of the leaf powder of $S$. siamea showing palisade cell.

in some constituents. The result of the qualitative phytochemical analysis is presented in Table 7.

\section{Quantitative Estimation of Phytocomponents}

The quantitative analysis of phytoconstituents of $S$. siamea leaves extract is shown in Table 8. flavonoids (6.1 $\%$ ) and saponins (4.2\%) are the highest phytochemical component in the leave extract, while alkaloids $(2.3 \%)$ and Tannins (1.5\%) have lesser phytochemical components.

\section{Result of Pharmacological Analysis}

\section{Toxicological Studies}

\section{Acute Toxicity Test}

Result of oral acute toxicity study in mice (Table: 9) revealed no lethality at any of the administered doses between $100 \mathrm{mg} / \mathrm{kg}$ and $5000 \mathrm{mg} / \mathrm{kg}$.

\section{Result of the Biochemical Assay}

The increase in ALT, AST and ALP when both the crude 
Table 6: Retardation Factors $\left(\mathrm{R}_{\mathrm{f}}\right.$ - values) methanolic Extracts in Acetone: Water: 25\% Ammonium hydroxide 9:7:3), n-Hexane:Ethyl acetate: Ammonium hydroxide (4:5:1), $\mathrm{n}$-Hexane :Ethyl acetate (7:3)

\begin{tabular}{lll}
\hline Solvent system & spot & $R_{f}$-value \\
\hline & 1 & 0.31 \\
$\mathrm{R}_{\mathrm{f}}$ values in acetone: Water: & 2 & 0.40 \\
25\% ammonium hydroxide(9:7:3) & 3 & 0.54 \\
& 4 & 0.67 \\
$\mathrm{R}_{\mathrm{f}}$ values in n-Hexane & 1 & 0.12 \\
$:$ Ethyl acetate: ammonium & 2 & 0.84 \\
hydroxide(4:5:1) & & \\
$\mathrm{R}_{\mathrm{f}}$ values in & 1 & 0.1 \\
Hexane :Ethyl acetate $(7: 3)$ & 2 & 0.25 \\
& 3 & 0.77 \\
\hline
\end{tabular}

Table 7: The result of the qualitative phytochemical analysis

\begin{tabular}{llllll}
\hline S. N. & Phytochemical & \multicolumn{5}{c}{ Relative abundance } \\
\hline \multicolumn{7}{l}{ Constituents } & CE & BF & EF & HF \\
\hline 1 & Flavonoids & + & - & + & + \\
2 & Saponins & + & + & + & - \\
3 & Proteins & + & + & - & + \\
4 & Steroids & - & - & - & - \\
5 & Terpenoids & - & - & - & - \\
6 & Tannins & + & + & + & + \\
7 & Carbohydrates & + & - & + & - \\
8 & Reducing & + & - & + & + \\
& sugars & & & & \\
9 & Alkaloids & + & + & + & - \\
9 & Glycosides & + & - & + & + \\
\hline
\end{tabular}

The key:

$\mathrm{CE}=$ Crude extract

$\mathrm{BF}=$ Butanol fraction

$\mathrm{EF}=$ Ethyl acetate fraction

$\mathrm{HF}=\mathrm{n}$-hexane fraction

$-=$ Not present

$+=$ Present

Table 8: Quantitative estimation of phytoconstituents in S. siamea leaves

\begin{tabular}{ll}
\hline Phytoconstituents & Percentage Composition (\%) \\
\hline Alkaloids & 2.3 \\
Tannins & 1.5 \\
Saponins & 4.2 \\
Flavonoids & 6.1AVONOIDCTTRYE ANALYSIS OF \\
& Picralima nitida Seed and Pod extract \\
\hline
\end{tabular}

Table 9: Results of acute toxicity $\left(\mathrm{LD}_{50}\right)$ test

\begin{tabular}{llll}
\hline Phase & Dose $(\mathrm{mg} / \mathrm{kg})$ & No. of death & Behavior \\
\hline \multirow{4}{*}{ I } & 10 & $\% / 3$ & Normal \\
& 100 & $0 / 3$ & Normal \\
& 1000 & $0 / 3$ & Normal \\
II & 2000 & $0 / 1$ & Normal \\
& 3000 & $0 / 1$ & Normal \\
& 4000 & $0 / 1$ & Normal \\
\hline
\end{tabular}

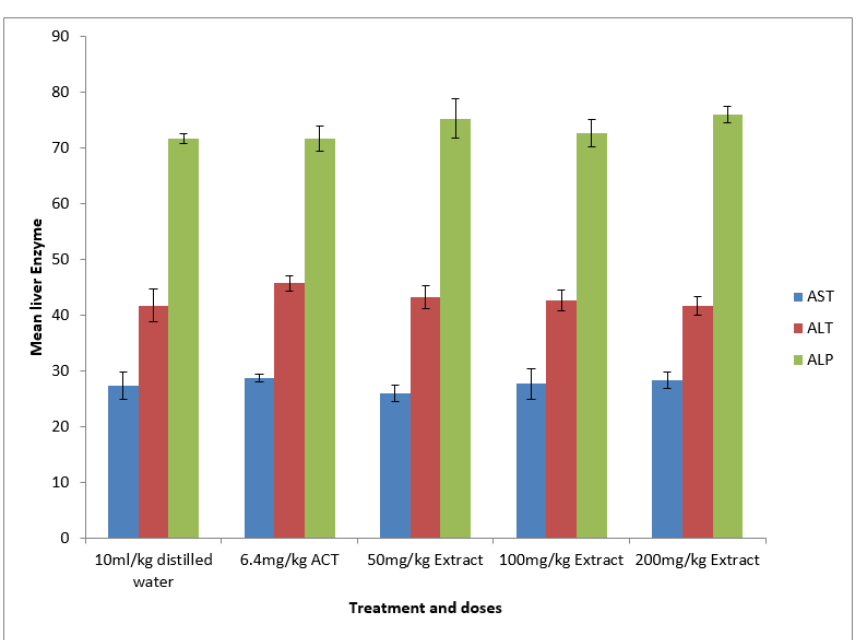

Figure 7: Multiple bar chart representing effect of extracts on liver enzymes

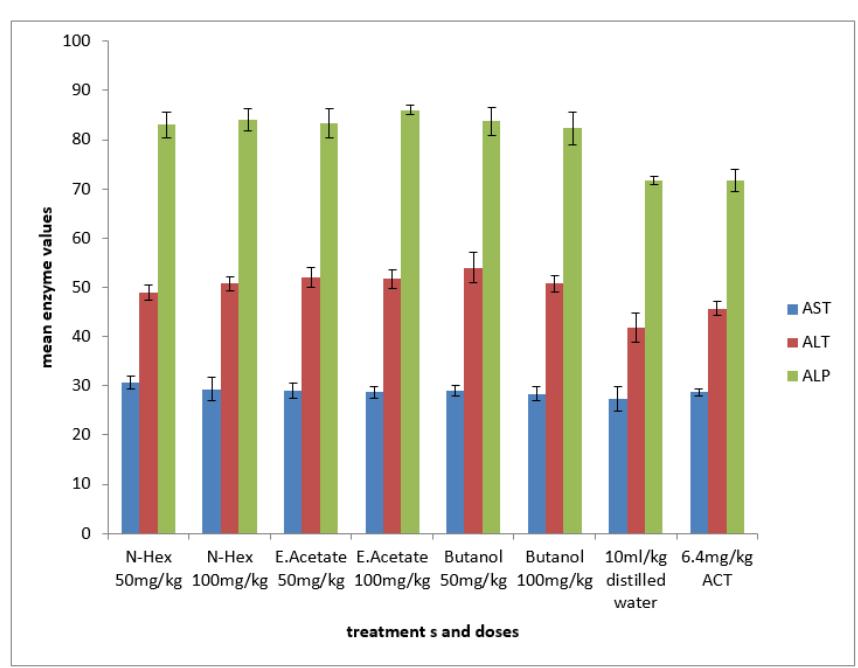

Figure 8: A multiple bar chart representing effect of fractions on liver enzymes.

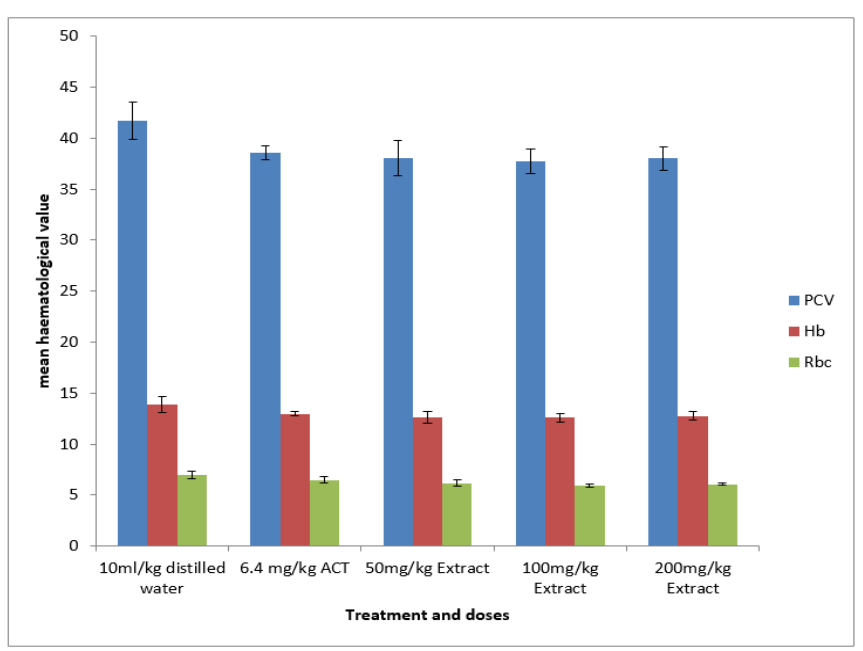

Figure 9: A multiple bar chart of mean haematological parameter against treatments with different doses of $S$. siemea extract

extract and fractions of $S$. siamea were administered were not statistically different from the control group, indicating no hepatotoxic potential. The results are presented below in Figures 7 and 8. 


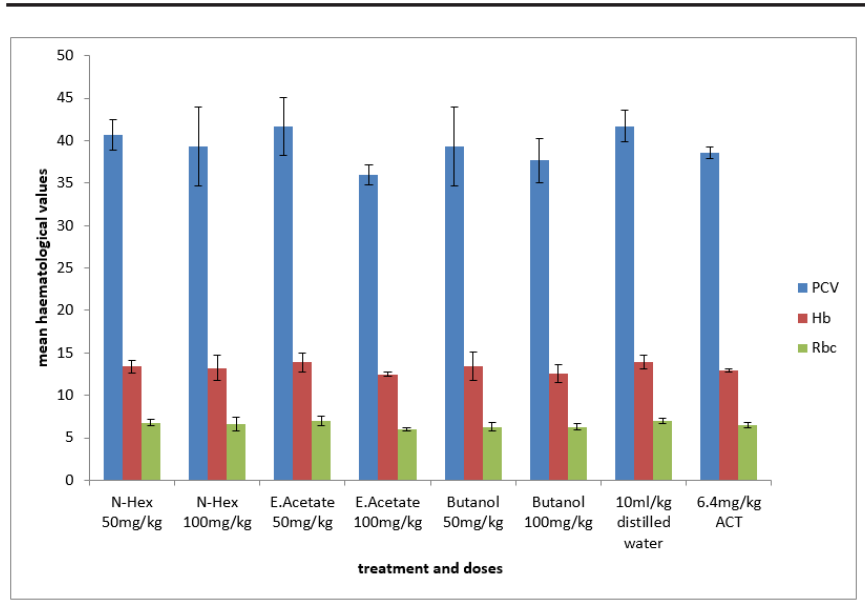

Figure 10: A multiple bar chart of mean hematological parameter against treatments with different doses of the fractions.

\section{Result of Hematological Studies}

The increase in PCV, $\mathrm{Hb}$ and $\mathrm{RBC}$ when both the crude extract and fractions of $S$. siemea were administered were not statistically different from the control group. The results are presented below in Figures 9 and 10.

\section{DISCUSSION}

The macroscopic examination of the whole leaves of $S$. siamea showed that it has an entire margin lamina, acute apex, etc., while organoleptic evaluation reveals the frontal surface of the leaf to be dark green in color and with a bitter taste. For proper identification, macroscopic determination of plants is the first step towards establishing its identity and purity; hence, it should be carried out before any test is undertaken (Khandelwal, 2007). The water-soluble and alcohol soluble extractive values are 8.2 and $6.1 \%$, respectively. The determination of water-soluble or alcohol-soluble extractive value is used to evaluate drugs, the constituents of which are not readily estimated by other means, and these extractive values are highly required pharmacopoeial standards thereby helps in judging the purity and quality of the drug (Evans, 2009).

The ash value of any organic matter is composed of their non-volatile inorganic component. The total ash, acid-insoluble ash and water-soluble ash for S. siamea were 10.6, 5.1 and 2.0\%, respectively. This is in line with Esievo et al., (2016) report which reported that the total ash, acid-insoluble ash, and water-soluble ash for $S$. siamea were $6.46,5.32$, and $1.87 \%$, respectively. The slight disparities in the values are possibly due to collection from different geographical regions (Anambra state and Niger state). This value may vary from plant to plant hence an important parameter in evaluation of crude drugs. The ash value may be raised by unwanted parts of drugs and contamination such as sand (Odoh et al., 2011). Moisture content is an index of water activity and is used as a measure of stability and susceptibility to microbial action (Okaka and Okaka, 2001; Aruah et al., 2012). Therefore, the low moisture content indicates that the leaves of $S$. siamea can be stored for a long period without deterioration. Low moisture content is always desirable for higher stability of drugs (Chandel et al., 2011). The moisture content of S. siamea leaf is $5.5 \%$. Which falls within limits for water content (8-14\%) for vegetable drugs (Abere and Onwukaeme, 2012). The moisture content was not high, indicating less chances of microbial degradation of the drug during storage because excess moisture can result in the breakdown of important constituents by enzymatic activity and, as a result, may encourage the growth of yeast and fungi during storage (Kendeson et al., 2018). Most drugs can be stored safely if the moisture content is kept as low as $6 \%$ or less (Ezugwu et al., 2011).

Thin layer chromatography (TLC) was carried out to establish an identification marker for the quality evaluation and standardization of the crude extract of $S$. siamea. In analytical TLC, one of the solvent system with three solvent mixtures (acetone: water: $25 \%$ ammonium hydroxide (9:7:3)) gave better separation by revealing four spots for methanol extract while the other solvent systems (n-Hexane: Ethyl acetate: Ammonium hydroxide (4:5:1); Hexane: Ethyl acetate (7:3) revealed two and three spots respectively. This gives an idea of the polarity of various chemical constituents so that constituent showing high retention fraction (Rf) value in less polar solvent has low polarity and with less $R_{\mathrm{f}}$ value have high polarity (Dutta, 2013). Plant material may vary in its chemical content and therefore in its therapeutic effect due to differences in environmental factors and species (Sahoo et al., 2010). Qualitative phytochemical screening revealed the presence of alkaloids, tannins, protein, carbohydrates, glycosides, saponins and flavonoids, and quantitative estimation of some phytochemicals showed that it contains more of flavonoids and lesser of tannins. These phytochemicals are known for their physiological actions such that they confer the therapeutic potentials of all medicinal plants (Ayoola et al., 2008; Saganuwan et al., 2011).

The $\mathrm{LD}_{50}$ of the crude extract is $>5000 \mathrm{mg} / \mathrm{kg}$ indicating its safety. The liver is the main tissue for the detoxification and metabolism of most chemicals. Liver enzymes including alanine aminotransferase (ALT), aspartate aminotransferase (AST), and alkaline phosphatase (ALP) usually help to detect liver disease by monitoring their concentration. The non-significant decrease in the levels of ALT, AST and AST indicates that the extract has possible hepatoprotective effect. The experimental mice's hematology and serum biochemical parameters also showed no significant changes in the 
groups administered with the crude extract and fractions compared to the control group $(p<0.05)$. This result showed that there was no significant change in most of the parameters in the experimental mouse group. Also, no significant changes $(p<0.05)$ were observed in the $\mathrm{PCV}, \mathrm{Hb}$ and $\mathrm{RBC}$ in all the groups as compared to basal indicating that the extract does not affect the heamatopoietic system when administered orally and at the doses used in the study.

\section{CONCLUSION}

Pharmacognostic standards including the toxicity profile of $S$. siamea leaves was established in this study and will be added to the plant's monograph for incorporation in the herbal pharmacopeia.

\section{REFERENCES}

1. Abere, A.T., Onwukaeme, N.D. (2012). Pharmacognostic evaluation of the leaves of Secamone afzelii (Schult) K. Schum (Asclepiadaceae). Trop. J. Pharm. Res. 11(1): 125 - 131.

2. Aruah, B.C., Uguru, M.I. and Oyiga, B.C. (2012). Genetic variability and interrelationships among some Nigerian pumpkin accessions (Cucurbita spp.). Int. J. Plant Breeding 6(1): 34 - 41.

3. Ayoola, G.A., Coker, H.A., Adesegun, S.A., Adepoju-Bello, A.A., Obaweya, K., Ezennia, E.C. and Atangbayila, T.O. (2008). Phytochemical screening and antioxidant activities of some selected medicinal plants used for malaria therapy in Southwestern Nigeria. Trop. J. Pharm. Res., 7: 1019 - 1024.

4. Baheti, J.R., Goyal, R.K., Gaurang, B. Shah. (2006). Hepatoprotective activity of Hemidesmus indicus R. Br. in rats. Indian J. Experimental Biol. 44(5): 399 - 404.

5. Chandel, H.S., Pathak, A. K., and Tailang, M. (2011). Standardization of some herbal anti-diabetic drugs in polyherbal formulation. Pharmacognosy Res. 3(1): 49 - 56.

6. Chang, C., Yang, M., Wen, H. and Chern, J. (2002). Estimation of total flavonoid content in propolis by two complementary colorimetric methods. J. Food Drug Analysis, 10: 178 - 182.

7. Cunny, H.C., Mayes, B.A., Rosica, K.A., Trutter, J.A., Van Miller, J.P. (1997). Subchronic toxicity (90 - Day) study with para-nonylphenol in rats. Regulatory Toxicol. and Pharmacol. 26(2): $172-178$.

8. Dutta, J. (2013). Phytochemical analysis and TLC fingerprinting of methanolic extract of medicinal plants. Int. Res. J. Pharmacy. 4(6): 123 - 126.

9. El-mahmood, A.M., Doughari, J.H. (2008). Phytochemical screening and anti-bacterial evaluation of the leaf and root extracts of Cassia alata. Afr. J. Pharm. Pharmacol. 2(7): 124 - 129.

10. Esievo, K.B., Fatokun, O. T., Ibrahim, J. A., and Kunle, O. F. (2016). Pharmacognostic studies of the leaf of Senna siamea (lam.) Irwin \& Barneby Family: Caesalpiniaceae. Europ. J Medicin. Plants. 16(2): 1 - 7.

11. Evans, W.C. (2009). Textbook of Pharmacognosy, $16^{\text {th }}$ Edition.,Elsevier Limited, China. 14 -125.

12. Ewuram, G.A. (2009). Pharmacognostic study of Jatropha curcas Linn. (Euphobieceae), MSc project (Pharmacognosy and Enviromental Medicine) Submitted to the University of Nigeria, Nsukka, $14-25$.
13. Ezugwu, C.O., Odoh, U.E. and Ezea, S.C. (2011). Determination of pharmacognostic standards of medicinal plant. Paschal Communications, Nsukka, Enugu, Nigeria. 38 - 47.

14. Gills, L.S. (1992). Ethnomedical uses of plants in Nigeria, University of Benin Press, Nigeria. 276.

15. Harbourne, J.B.C. (1973). Phytochemical Methods, Chapman and Hall, London. $49-51$.

16. Inya-Agha, S.I. (2006). Hand book of phytomedicine and therapeutics in the tropics, MASON Printer and Publishers, Enugu. 20 - 34.

17. Kendeson, A.C., Abdulkadir, A.G., Danja, A.B., Abdu, Z. and Alfazazi, A. (2018). Phytochemical screening, proximate and elemental analyses of Senna siamea (Lam.) leaves from Kashere metropolis of Gombe State, Nigeria. Int. Res. J. Chemistry and Chemical Scis. 5(1): 082 - 085.

18. Khandelwal, KR (2007). Practical pharmacognosy techniques and experiment.17 ${ }^{\text {th }}$ edition, Pune: Nirali, Prakashan.

19. Kupradinun, P., Tepsuwan, A., Tantasi, N., Meesiripun, N., Rungsipipat, A., Kusamran, W.R. (2011). Anticlastogenic and anticarcinogenic potential of Thai bitter: Gourd fruits. Asian Pac. J. Cancer Prevention. 12(5): 1299 - 1305.

20. Lorke, D. (1983). A new approach to practical acute toxicity testing. Arch toxicol. 54: 257 - 287.

21. Lose, G.A., Bernard, S.J., Leihner, D.E. (2000). Studies on agro forestry hedgerow system with Senna siamea rooting patterns and competition effects. J. Sci. 38: 57 - 60.

22. Morales, M.A., Hernández, D., Bustamante, S., Bachiller, I., Rojas, A. (2009). Is senna laxative use associated to cathartic colon, genotoxicity, or carcinogenicity? J. Toxicol. $1-8$.

23. Nsonde Ntandou, G.F., Banzouzi, J.T., Mbatchi, B., ElionItoua, R.G.D., EtouOssibi, A.W., Ramos, S., Benoit-Vicale, B., Abena, A.A., Ouamba, J.M. (2010). Analgesic and antiinflammatory effects of Cassia siamea Lam stem bark extracts. J. Ethnopharmacol. 127:108-111.

24. Obadoni, B.O. and Ochuko, P.O. (2001). Phytochemical studies and comparative efficacy of the crude extracts of some homeostatic plants in Edo and Delta states of Nigeria. Global J. Pure Applied Scies. 8: 203 - 208.

25. Odason, E.E., Kolawole, J. (2007). Anti-diabetic properties and brine shrimp toxicity of the aqueous extract of the root of Cassia siamea Lam. (Ceasalpiniaceae). Nig. J. Pharm. Res. 6: $66-69$.

26. Odoh, R., Agbaji, E.B. and Kagbu, J.A. (2011). Assessment of trace metal pollution in auto-mechanic workshop in some selected Local Government Area of Benue State, Nigeria. Int. J Chem. 3(4): $78-88$.

27. Ogunkunle, A.T.S., Ladejobi, T.A. (2006). Ethnobotanical and phytochemical studies on some species of senna in Nigeria. Africa J. Biotech. 5(21): 2020 - 2023.

28. Okaka, J.C. and Okaka, A.N.O. (2001). Food composition, spoilage and shelf life extension. Ocjarco Academic Publisher Enugu Nigeria. 54: 56.

29. Onwuka, G.I. (2005). Food analysis and instrumentation theory and practice. Department of Food Science and Technology, Michael Okpara University of Agriculture, Umudike. Umuahia, Nigeria. 63 - 79.

30. Sachs, J. and Malaney, P. (2002). The economic and social burden of malaria.Nature 415(7): 680 - 685 .

31. Saganuwan, A.S., Patrick, A.O., Egoche, G.A. and Emmanuel, U.E. (2011). In vivo antiplasmodial activity by aqueous extracts of Abrus precatorius in mice. Rev. Latinoamer, 39: 1 - 2.

32. Sahoo, A., Singh, B., Bhat, T. (2010). Effect of tannins on in-vitro 
ruminal protein degradability of various tree forages. Livest. Res. Rural Dev. 22(7): 119.

33. Sati, S.H., Rawat, U., Sati, O.P. (2010). Medicinal plants as a source of antioxidants. Res. J. Phytochem. 4: 213 - 224.

34. Tripathi, A.K., Gupta, K.R. (1991). Phytochemical study of Cassia siamea. J. Ind. Chem. Soc. 68(4): 254 - 255.
35. Wongwitdecha, N. (2007). Neuro-psychopharma-cological studies the effects of barakol, a traditional Thai medicine. Srinagarind Medical Journal. 22: 325 - 332.

36. Woolley, A. (2008). A guide to practical toxicology, evaluation, prediction and risk. $2^{\text {nd }}$ ed., Informa Health Care. New York, London. 